\title{
Use of Fungal Laccases to Facilitate Biodethatching: A New Approach
}

\author{
Sudeep S. Sidhu, Qingguo Huang, Robert N. Carrow, \\ and Paul L. Raymer ${ }^{1}$ \\ Department of Crop and Soil Sciences, The University of Georgia, Griffin \\ Campus 1109 Experiment Street, Griffin, GA 30223
}

Additional index words. Agrostis stolonifera, lignolytic enzymes, lignin, thatch layer, organic matter, turfgrass

\begin{abstract}
Accumulation of excessive organic matter as thatch restricts permeability of putting greens and is one of the most difficult problems in turfgrass management. A greenhouse experiment using potted bentgrass (Agrostis stolonifera L.) determined the efficacy of a ligninolytic enzyme, laccase, in reducing organic matter accumulation in the thatch-mat layer. Laccase was added biweekly at $0,0.206,2.06$, and 20.6 units of activity $/ \mathrm{cm}^{2}$ with and without guaiacol (2-methoxyphenol), a mediator of laccase, and sampling was performed after two and nine months. Parameters investigated included thickness of the organic layer, thatch layer and mat layer, organic matter content, saturated hydraulic conductivity, and lignin content. Organic matter and thatch layer increased between the two sampling dates in all treatments. Laccase was shown to be effective in slowing the rate of accumulation of organic matter and thatch layer. After two months, application of 20.6 units $/ \mathrm{cm}^{2}$ of laccase reduced organic layer thickness by $8.7 \%$ and extractive-free total lignin content by $8.4 \%$ when compared with non-treated control. After nine months, laccase application rates of 2.06 units $/ \mathrm{cm}^{2}$ reduced organic matter and thatch layer thickness by $15.6 \%$ and $45.0 \%$, respectively, below levels observed in the non-treated control. Applications using 0.206 units $/ \mathrm{cm}^{2}$ of laccase were ineffective. Laccase applications had no influence on turf quality. These positive responses suggest laccase treatments could be a non-disruptive option for thatch and/or mat control in bentgrass.
\end{abstract}

Formation of thatch and mat layers is one of the major problems in management of modern turfgrass golf greens. Thatch is a layer of organic matter that accumulates between the soil and green turfgrass and contains both living and dead plant tissues intermingled tightly with each other. Thatch consists of stolons, rhizomes, roots, crown tissue, leaf sheaths, and blades (Engel, 1954; Roberts and Bredakis, 1960). The mat layer is generally below the thatch layer and is distinguished from thatch by the presence of sand or soil intermingled with thatch as a result of cultural practices like core aeration and topdressing (McCarty, 2005). A small amount of organic matter reduces surface hardness, moderates soil temperature extremes, increases the resilience, and improves wear tolerance of the turfgrass surface (Beard, 1973); however, excessive thatch and mat layers are undesirable in turfgrass.

High organic matter accumulation in the form of thatch-mat causes problems such as

Received for publication 10 May 2012. Accepted for publication 8 Aug. 2012.

The research was supported by funding from the Golf Course Superintendents Association of America, Georgia Golf Environmental Foundation, and Georgia Agricultural Experiment Stations.

We thank Rashmi Singh, Qi Luo, Lewayne White, and Rodney Connell for their excellent technical assistance.

${ }^{1}$ To whom reprint requests should be addressed; e-mail praymer@uga.edu. decreased movement of oxygen through the thatch or mat zone, decreased saturated hydraulic conductivity, and excessive water retention (Carrow, 2003; Hartwiger, 2004; McCarty et al., 2007). These primary problems may further lead to secondary problems like wet wilt, soft surface, black layer, limited rooting, and extra- and intracellular freezing damage (Beard, 1973; Carrow, 2004; O'Brien and Hartwiger, 2003). Although structured organic matter, present in live underground plant tissues, is thought to have no adverse effect on the soil physical properties, rapid root death that results in dead gelatinous organic matter swells in the presence of water during decomposition and plugs the soil macropores (air-filled pores), causing low oxygen levels in the root zones (Carrow, 2004; O'Brien and Hartwiger, 2003). Excessive accumulation of organic matter causes anaerobic conditions, further reducing the rate of organic matter decomposition (McCoy, 1992). Grasses also generally produce more adventitious roots (surface roots) during anaerobic conditions, again further increasing organic matter content (Carrow, 2004).

Thatch management techniques such as core aeration, vertical mowing, grooming, and topdressing are currently the most effective strategies to manage thatch-mat buildup but have shown contrasting results (Barton et al., 2009; Carrow et al., 1987; Dunn et al., 1981; McCarty et al., 2005; McWhirter and Ward, 1976; Weston and Dunn, 1985; White and Dickens, 1984). These cultural practices are intensive in terms of cost, energy, and labor and have adverse effects on turfgrass quality (Barton et al., 2009; Landreth et al., 2008; McCarty et al., 2007). Several nondestructive thatch control studies using glucose, cellulase solutions (Ledeboer and Skogley, 1967), and commercial inocula containing various microorganisms were ineffective in reducing the amount of thatch (McCarty et al., 2005; Murdoch and Barr, 1976). Reduction in cellulose content and total oxidizable organic matter of bermudagrass (Cynodon dactylon L.) and centipedegrass (Eremochloa ophiuroides) (Sartain and Volk, 1984) and weight loss of bermudagrass pellets, St. Augustinegrass [Stenotaphrum secundatum (Walt.) Kuntze], and zoysiagrass (Zoysia japonica Stued., 'Meyer') stolons (Martin and Dale, 1980) was observed when inoculated with different wood-decaying fungi under controlled greenhouse and laboratory conditions. However, field inoculation experiments on bermudagrass showed no thatch degradation (Martin and Dale, 1980).

The formation of the thatch-mat layer is the result of a greater rate of organic matter accumulation than degradation (Beard, 1973). Most microbial degradation mechanisms are restricted by the presence of lignin, a plant cell wall constituent. The slow decomposition of soil lignin has long been recognized (Kirk and Farrell, 1987). Lignin limits the accessibility of microbial degraders to more biodegradable plant materials such as cellulose and hemicelluloses (Ledeboer and Skogley, 1967). Lignin is formed in plants by oxidative coupling of monolignols of three primary hydroxycinnamyl alcohols: p-coumaryl, coniferyl, and sinapyl alcohols. The corresponding lignin monomers are known as $p$-hydroxy phenyl, guaiacyl, and syringyl units, respectively (Wong, 2009). Lignification is achieved by crosslinking of monomers with a growing polymer through polymer-polymer coupling. Based on the random coupling theory, several models of lignin molecular structure have been proposed but these models do not imply any particular sequence of monomeric units in the lignin macromolecule (Chen and Sarkanen, 2003; Davin and Lewis, 2003).

Natural degradation of lignin occurs in the environment by certain white-rot fungi, which solubilize and mineralize lignin with the help of lignolytic enzymes (Kirk et al., 1975, 1976). White-rot fungi preferentially attack lignin more than cellulose or hemicellulose in the wood tissue (Blanchette, 1984; Mester et al., 2004). This process of selective delignification exposes cellulosic materials for further bacterial degradation in the environment (Otjen and Blanchette, 1987). The presence of naturally occurring (guaiacol) and synthetic (1-hydroxybenzotriazole) chemicals, known as mediators, have been shown to enhance the activity of the lignolytic enzyme laccase (Kang et al., 2002; Roper et al., 1995). Because lignin content in thatch layer is higher than that of live grass tissues, the thatch layer in turfgrass species with high lignin content is more resistant to microbial decomposition (Beard, 1973; Ledeboer and Skogley, 1967). 
We hypothesize that the use of lignindegrading enzymes such as fungal laccases can effectively reduce the rate of thatch layer accumulation in golf greens. The objectives of our study were: 1) to determine if degradation of soil organic matter can be enhanced by laccase application; 2) to determine if addition of guaiacol enhances laccase efficacy in organic matter decomposition; and 3 ) to determine if application of laccase enzyme and guaiacol adversely affect turf quality.

\section{Materials and Methods}

A greenhouse experiment was conducted using 'Crenshaw' creeping bentgrass Agrostis stolonifera L. (Engelke et al., 1995), established in pots (top diameter $15 \mathrm{~cm}$, height $11.5 \mathrm{~cm}$ ) at The University of Georgia, Griffin Campus, from Oct. 2008 to July 2009. The bentgrass was acquired from East Lake Country Club, Atlanta, GA. Pots were partially filled with $85: 15$ sand and organic matter mix and $\operatorname{sod} \approx 3 \mathrm{~cm}$ in thickness was cut to fit the pots and placed on top of the mix. All pots were established in June 2008 and grown under management conducive to thatch development in a controlled environment greenhouse for about four months before initiation of treatments. Pots were irrigated daily, fertilized monthly with a $50 \mathrm{~mL}$ solution of $0.4 \%(w / v)$ Macron water soluble $28 \mathrm{~N}-7 \mathrm{P}$ $14 \mathrm{~K}$ fertilizer (Lesco, Strongsville, $\mathrm{OH}$ ), and maintained by hand clipping weekly at a height of $0.6 \mathrm{~cm}$ with clippings removed. The refrigerated air-conditioned greenhouse was maintained at $25 \pm 2 / 18 \pm 2{ }^{\circ} \mathrm{C}$ day/night temperature by a Wadsworth Step 50 controller (Wadsworth Control System, Arvada, $\mathrm{CO})$ under natural lighting ( $\approx 85 \%$ ambient light).

The treatment design was as a four-bytwo factorial with all combinations of four levels of laccase and two levels of guaiacol (2-methoxyphenol). The four laccase activity levels were 0 (control), 0.206, 2.06, and 20.6 units $/ \mathrm{cm}^{2}$ and guaiacol levels were 0 and $0.1 \mathrm{M}$ solution. The experimental design was a randomized complete block with five replications and sampling times of two and nine months. Forty-milliliter solutions of the different laccase activity levels and $10 \mathrm{~mL}$ of guaiacol solutions were applied uniformly every 2 weeks to each pot using a handheld sprayer. The control pots were treated with equivalent amounts of distilled water. After the two months of treatment applications, the 20.6 units $/ \mathrm{cm}^{2}$ treatments with and without guaiacol were discontinued as a result of limited availability of laccase enzyme. As a result of unexpected problems in developing protocols for measurement of saturated hydraulic conductivity, one replication was rendered unusable for measurement of other variables. Therefore, only four replications were used for analysis after nine months' treatment duration.

Laccase activity assay. The laccase enzyme from Trametes versicolor, a white-rot fungus, was purchased from Sigma-Aldrich (Product 53739; Sigma Aldrich Inc., St. Louis,
MO). Laccase solutions were standardized based on active units, which were quantified using a ultraviolet/VIS-spectrophotometer by a colorimetric assay. One activity unit of laccase corresponds to the amount of enzyme that causes an absorbance change at $468 \mathrm{~nm}$ at a rate of 1.0 unit $/ \mathrm{min}$ in $3.4 \mathrm{~mL}$ of $1 \mathrm{~mm}$ 2,6-dimethoxyphenol, a specific substrate for laccase, in citrate-phosphate buffer at $\mathrm{pH} 3.8$ (Park et al., 1999). Laccase activity treatments of 0 (control), 0.206, 2.06, and 20.6 units $/ \mathrm{cm}^{2}$ actually correspond to laccase solutions with activity levels of $0,0.912,9.12$, and 91.2 units $/ \mathrm{mL}$, respectively. The activity level of laccase applied per unit area was calculated by dividing the total number of units of laccase in $40 \mathrm{~mL}$ laccase solution by the top surface area of the pot.

Measurements. Effectiveness of treatments was determined by measuring organic matter content $(\mathrm{OM})$ for a depth of 0 to $5.0 \mathrm{~cm}$, organic layer thickness (OL), extractive-free acid-soluble lignin $\left(\mathrm{L}_{\mathrm{S}}\right)$, and acid-insoluble lignin $\left(\mathrm{L}_{\mathrm{I}}\right)$ content after two and nine months of treatment application. Total lignin was obtained by addition of acid-soluble andinsoluble lignin contents.

After nine months of treatment application, some additional variables were measured. OL was subdivided into thatch layer thickness $\left(\mathrm{OL}_{\mathrm{T}}\right)$ and mat layer thickness $\left(\mathrm{OL}_{\mathrm{M}}\right)$, whereas $\mathrm{OM}$ was subdivided into 0 to 2.5 and 2.5 to $5.0 \mathrm{~cm}$ depths to more accurately reflect the effectiveness of laccase on the thatch and mat layers. Saturated hydraulic conductivity (SHC) was also measured after nine months.

Organic matter content. The measurement of OM was performed as described by Carrow et al. (1987). Soil cores $(2.0 \mathrm{~cm}$ diameter) were dried in an oven at $100 \pm 5{ }^{\circ} \mathrm{C}$ for $48 \mathrm{~h}$ and weighed. Soil cores were ashed in a muffle furnace at $600 \pm 10^{\circ} \mathrm{C}$ for $24 \mathrm{~h}$ and weighed again. Organic matter content was determined as the difference in the two readings and percent OM was calculated.

Saturated hydraulic conductivity. Intact cores (diameter $4.7 \mathrm{~cm}$ and length $7.7 \mathrm{~cm}$ ) were obtained from the center of each pot using a soil corer. The cores were collected in brass cylinders. The bottom of the core was covered with a double layer of cheesecloth held in place with a rubber band. The core was saturated overnight in a $0.05 \mathrm{~N} \mathrm{CaCl}_{2}$ solution to minimize dispersion. A clear plastic cylinder of the same diameter as of the brass cylinder was fastened above the brass cylinder with paraffin wax tape. The SHC of the cores was measured by a constant hydraulic head method using a Marriott tube apparatus. A time of $10 \mathrm{~min}$ was allowed for the establishment of steady-state flow through the samples. The volume of water that passed through the core was measured for $1 \mathrm{~min}$ and repeated three times. Saturated hydraulic conductivity was calculated using Darcy's equation.

Organic layer thickness and thatch-mat layer thickness. After cores were removed for measurement of OM content and SHC, plants were removed from pots and distinct separations among the thatch, mat, and soil interface were clearly visible. The $\mathrm{OL}, \mathrm{OL}_{\mathrm{T}}$, and $\mathrm{OL}_{\mathrm{M}}$ were measured from seven different locations around the edges of the plant/ root mass and averaged.

Extractive-free lignin content. Thatch was collected from each pot from the top $2.5 \mathrm{~cm}$ after sampling for OM and SHC. Extractivefree acid-soluble and -insoluble lignin content in the thatch layer was determined in a two-step hydrolysis procedure according to the laboratory analytical procedure developed by The National Renewable Energy Laboratory (NREL, 2008). In the first step, extractive-free thatch samples were hydrolyzed for 60 min with $72 \% \mathrm{H}_{2} \mathrm{SO}_{4}$ at $30{ }^{\circ} \mathrm{C}$. In the second step, $\mathrm{H}_{2} \mathrm{SO}_{4}$ was diluted to $4 \%$ and the samples were autoclaved at $121{ }^{\circ} \mathrm{C}$ for $1 \mathrm{~h}$. Acid-soluble lignin was determined by measuring the absorbance of this hydrolysis liquid at $240 \mathrm{~nm}$ in a ultraviolet/VIS spectrophotometer. The solids remaining after acid hydrolysis were dried in an oven at $100 \pm 5^{\circ} \mathrm{C}$ for $24 \mathrm{~h}$, weighed, ashed in a muffle furnace at $600 \pm 10^{\circ} \mathrm{C}$ for $24 \mathrm{~h}$, and weighed again. Weight difference was used to calculate the acid-insoluble lignin content.

Turf quality. Turf quality was determined biweekly for the first three months and again for the last two months of the experiment to document the potential for initial and longterm phytotoxicity associated with laccase application. The turf quality of each treatment was recorded every 2 weeks by rating both visual turf quality and canopy spectral reflectance. Visual turf quality ratings were rated on the basis of color, shoot density, and uniformity on a numerical scale where 1 equals no live turf and 9 equals ideal dark green, uniform turf (Johnson et al., 1987) Grass index was determined using a TCM 500 turf color meter (Spectrum Technologies, Plainfield, IL). Grass index is a numerical score of the color and density of grass based on the spectral reflectance at 660 and $850 \mathrm{~nm}$. Three grass index readings were recorded from each pot and averaged for statistical analysis.

Statistical analysis. Analysis of variance (ANOVA) was performed to evaluate the main effects of treatment duration, laccase, and guaiacol and interaction effects of these three factors using the general linear model (SAS Institute Inc., 1994). Strong treatment duration effects $(P \leq 0.001)$ were observed in the initial analysis and therefore each treatment duration was analyzed separately using ANOVA as a two-factor study consisting of four levels of laccase enzyme and two levels of guaiacol for the two months' treatment duration and three levels of laccase enzyme and two levels of guaiacol for the nine months' treatment duration. Fisher's protected least significant difference test with $\alpha=0.05$ was used for determining statistical differences among treatment means after each ANOVA.

\section{Results}

The full statistical model was used to compare common parameters at the two- and 


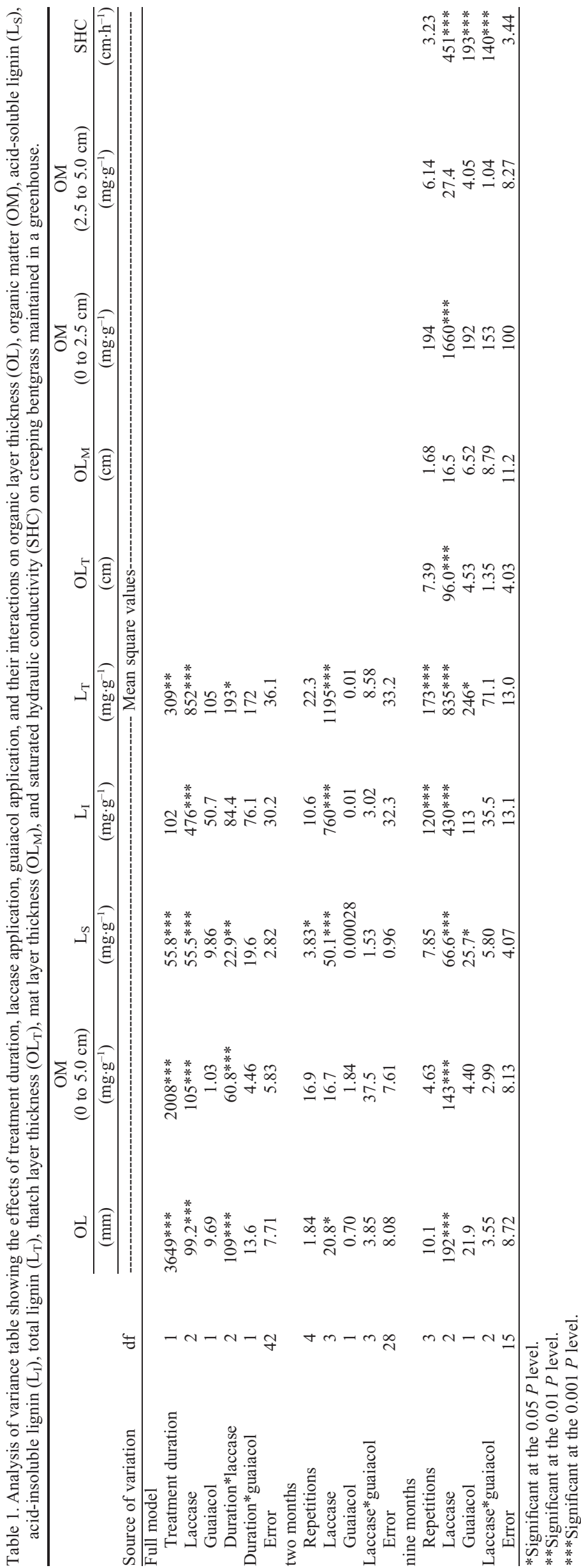

nine-month sampling dates (Table 1). The model included the main and interaction effects of treatment duration, three levels of laccase, and two levels of guaiacol for OM ( 0 to $5.0 \mathrm{~cm}), \mathrm{OL}, \mathrm{L}_{\mathrm{S}}$, andL $\mathrm{L}_{\mathrm{I}}$. Only three levels of laccase were used because the 20.6 units $/ \mathrm{cm}^{2}$ laccase treatment was discontinued after two months of application.

Treatment duration strongly affected $\mathrm{OM}$ (0 to $0.5 \mathrm{~cm} ; P \leq 0.001)$, OL $(P \leq 0.001)$, and $\mathrm{L}_{\mathrm{S}}(P \leq 0.001)$ (Table 1$)$. Laccase application significantly affected $\mathrm{OM}(0$ to $5.0 \mathrm{~cm}), \mathrm{OL}, \mathrm{L}_{\mathrm{S}}$, and $\mathrm{L}_{\mathrm{I}}$. The very strong interactions for treatment duration and laccase treatment observed in OM (0 to $0.5 \mathrm{~cm}$; $P \leq 0.001)$, OL $(P \leq 0.001)$, and $\mathrm{L}_{\mathrm{S}}(P \leq$ 0.01 ) were largely the result of the lack of response to laccase treatments after two months as opposed to a strong response seen after nine months. Guaiacol treatment as well as the interaction of guaiacol and treatment duration had no effect on any of the parameters (Table 1).

We observed an overall increase in $\mathrm{OM}(0$ to $5.0 \mathrm{~cm}$ ) and $\mathrm{OL}$ in all treatments between the two sampling dates. However, accumulation of OM (0 to $5.0 \mathrm{~cm})$ and OL was significantly lower in treatments containing laccase when compared with the control. When compared with the control, the rate of accumulation of $\mathrm{OM}$ (0 to $5.0 \mathrm{~cm}$ ) was reduced from $15.8 \mathrm{mg} \cdot \mathrm{g}^{-1}$ in control pots to $9.0 \mathrm{mg} \cdot \mathrm{g}^{-1}$ in pots treated with 2.06 units $/ \mathrm{cm}^{2}$ laccase $(43 \%)$ (Table 2). Similarly, application of 2.06 units $/ \mathrm{cm}^{2}$ laccase reduced OL accumulation from $15.5 \mathrm{~mm}$ to $11.7 \mathrm{~mm}$ (24\%) when compared with the control (Table 2). A reduction in lignin content between the two sampling dates was observed at laccase activity levels of 2.06 units $/ \mathrm{cm}^{2}$ with and without guaiacol (Table 3).

Analysis after two months' treatment. After two months of treatment application, laccase treatments had no effect on $\mathrm{OM}$ $(0$ to $5.0 \mathrm{~cm})$ but had significant effects on $\mathrm{OL}, \mathrm{L}_{\mathrm{S}}$ and $\mathrm{L}_{\mathrm{I}}$ (Table 1). Neither guaiacol nor the laccase by guaiacol interaction had significant effects on any of the parameters (Table 1).

Compared with the control, treatment with 20.6 units $/ \mathrm{cm}^{2}$ of laccase without guaiacol for two months significantly lowered $\mathrm{L}_{\mathrm{S}}$ by $5.2, \mathrm{~L}_{\mathrm{I}}$ by 20.5 , and $\mathrm{L}_{\mathrm{T}}$ content by 25.6 $\mathrm{mg} \cdot \mathrm{g}^{-1}$ (Table 3). Similarly, treatment at the same laccase activity with guaiacol reduced $\mathrm{L}_{\mathrm{S}}$ by $4.2, \mathrm{~L}_{\mathrm{I}}$ by 18.9 , and $\mathrm{L}_{\mathrm{T}}$ by $23.4 \mathrm{mg} \cdot \mathrm{g}^{-1}$ when compared with control. Treatment with 2.06 units $/ \mathrm{cm}^{2}$ of laccase with guaiacol also significantly reduced $\mathrm{L}_{\mathrm{S}}$ by $1.4 \mathrm{mg} \cdot \mathrm{g}^{-1}$ (Table 3).

Analysis after nine months' treatment. After nine months of treatment application, laccase application impacted OM (0 to 5.0 and 0 to $2.5 \mathrm{~cm}), \mathrm{SHC}, \mathrm{OL}, \mathrm{OL}_{\mathrm{T}}, \mathrm{L}_{\mathrm{S}}$, and $\mathrm{L}_{\mathrm{I}}$, and SHC $(P \leq 0.001)$ (Table 1). A significant effect of guaiacol was also observed for $\mathrm{L}_{\mathrm{S}}$ $(P \leq 0.05)$ and $\mathrm{SHC}(P \leq 0.01)$ (Table 1$)$. The interaction of laccase by guaiacol was significant $(P \leq 0.01)$ for SHC. However, none of the treatments affected OM (2.5 to $5.0 \mathrm{~cm}$ ) or mat layer thickness after nine months of treatment application. 
Table 2. Organic layer thickness (OL) and organic matter (OM) content ( 0 to $5.0 \mathrm{~cm}$ depth) after two and nine months of different treatments applied to creeping bentgrass. $^{z}$

\begin{tabular}{|c|c|c|c|c|}
\hline \multirow[b]{3}{*}{ Treatment $^{\mathrm{y}}$} & \multicolumn{2}{|c|}{ Organic layer thickness } & \multicolumn{2}{|c|}{ Organic matter (0 to 5.0$)$} \\
\hline & two months & nine months & two months & nine months \\
\hline & \multicolumn{2}{|c|}{ - } & \multicolumn{2}{|c|}{-- } \\
\hline$\overline{\text { OL (control) }}$ & $48.4 \mathrm{a}^{\mathrm{x}} \mathrm{B}^{\mathrm{w}}$ & 69.3 a A & 33.7 a B & 49.5 a A \\
\hline $0 \mathrm{~L}+\mathrm{G}$ & 47.4 a B & $68.2 \mathrm{ab} \mathrm{A}$ & $34.4 \mathrm{a} B$ & $47.3 \mathrm{a} \mathrm{A}$ \\
\hline $0.206 \mathrm{~L}$ & 45.7 a B & $67.3 \mathrm{ab} \mathrm{A}$ & 36.4 a B & $50.0 \mathrm{a} \mathrm{A}$ \\
\hline $0.206 \mathrm{~L}+\mathrm{G}$ & 47.6 a B & $63.8 \mathrm{bc} \mathrm{A}$ & $34.3 \mathrm{a} \mathrm{B}$ & $49.4 \mathrm{a} \mathrm{A}$ \\
\hline $2.06 \mathrm{~L}$ & $48.1 \mathrm{a} B$ & $59.8 \mathrm{~cd} \mathrm{~A}$ & 32.7 a B & $41.7 \mathrm{~b} \mathrm{~A}$ \\
\hline $2.06 \mathrm{~L}+\mathrm{G}$ & 47.7 a B & $58.5 \mathrm{~d} \mathrm{~A}$ & 35.0 a B & 41.9 b A \\
\hline $20.6 \mathrm{~L}$ & $44.2 \mathrm{~b}$ & - & $36.3 \mathrm{a}$ & - \\
\hline $20.6 \mathrm{~L}+\mathrm{G}$ & $45.1 \mathrm{a}$ & - & $33.9 \mathrm{a}$ & - \\
\hline
\end{tabular}

${ }^{2}$ The OM values are based on dry weight.

${ }^{y} \mathrm{~L}$ denotes laccase level and $\mathrm{G}$ the addition of guaiacol, a mediator.

'Means within a column followed by the same lowercase letter are not significantly different according to Fisher's protected least significant difference at $\alpha=0.05$.

"Means in a row within a parameter followed by the same uppercase letter are not significantly different according to Fisher's protected least significant difference at $\alpha=0.05$.

Table 3. Extractive-free acid-soluble $\left(\mathrm{L}_{\mathrm{S}}\right)$, acid-insoluble $\left(\mathrm{L}_{\mathrm{I}}\right)$, and total lignin $\left(\mathrm{L}_{\mathrm{T}}\right)$ content after two and nine months of different treatments applied to creeping bentgrass. $^{z}$

\begin{tabular}{|c|c|c|c|c|c|c|}
\hline \multirow[b]{3}{*}{ Treatment $^{\mathrm{y}}$} & \multicolumn{2}{|c|}{ Acid-soluble lignin } & \multicolumn{2}{|c|}{ Acid-insoluble lignin } & \multicolumn{2}{|c|}{ Total lignin } \\
\hline & two months & nine months & two months & nine months & two months & nine months \\
\hline & \multicolumn{2}{|c|}{ - } & \multicolumn{2}{|c|}{ - } & \multicolumn{2}{|c|}{ - } \\
\hline OL (control) & $43.7 \mathrm{ab}^{\mathrm{x}} \mathrm{A}^{\mathrm{w}}$ & $42.2 \mathrm{~b} \mathrm{~A}$ & 259.9 a A & $257.4 \mathrm{~b} \mathrm{~A}$ & $303.5 \mathrm{ab} \mathrm{A}$ & $299.7 \mathrm{~b} \mathrm{~A}$ \\
\hline $0 \mathrm{~L}+\mathrm{G}$ & $43.8 \mathrm{ab} \mathrm{A}$ & 45.8 a A & 260.1 a A & $264.8 \mathrm{a} \mathrm{A}$ & 303.9 a A & 310.6 a A \\
\hline $0.206 \mathrm{~L}$ & $44.1 \mathrm{a} \mathrm{A}$ & $41.4 \mathrm{~b} \mathrm{~A}$ & 256.9 a A & 254.5 bc A & $301.0 \mathrm{ab} \mathrm{A}$ & 295.9 b A \\
\hline $0.206 L+G$ & $43.3 \mathrm{abc} A$ & $41.4 \mathrm{~b} \mathrm{~A}$ & 255.4 a A & 253.9 bc A & $298.8 \mathrm{ab} \mathrm{A}$ & 295.5 b A \\
\hline $2.06 \mathrm{~L}$ & $42.7 \mathrm{bc} \mathrm{A}$ & $37.1 \mathrm{c} \mathrm{B}$ & 254.0 a A & $243.4 \mathrm{~d} \mathrm{~B}$ & $296.7 \mathrm{ab} A$ & $280.4 \mathrm{~d}$ B \\
\hline $2.06 \mathrm{~L}+\mathrm{G}$ & $42.3 \mathrm{c} \mathrm{A}$ & $39.5 \mathrm{bc} \mathrm{B}$ & 253.9 a A & 249.6 c A & 296.2 b A & 289.0 c B \\
\hline $20.6 \mathrm{~L}$ & $38.5 \mathrm{~d}$ & - & $239.4 \mathrm{~b}$ & - & $277.9 \mathrm{c}$ & - \\
\hline $20.6 \mathrm{~L}+\mathrm{G}$ & $39.5 \mathrm{~d}$ & - & $241.0 \mathrm{~b}$ & - & $280.1 \mathrm{c}$ & - \\
\hline
\end{tabular}

zThe extractive-free lignin values are based on dry weight.

${ }^{\mathrm{y}} \mathrm{L}$ denotes laccase level and $\mathrm{G}$ the addition of guaiacol, a mediator.

${ }^{\mathrm{x}}$ Means within a column followed by the same lowercase letter are not significantly different according to Fisher's protected least significant difference at $\alpha=0.05$.

wMeans in a row within a parameter followed by the same uppercase letter are not significantly different according to Fisher's protected least significant difference at $\alpha=0.05$.

Treatment with 2.06 units $/ \mathrm{cm}^{2}$ of laccase with and without guaiacol decreased OL by 10.8 and $9.5 \mathrm{~mm}$, respectively, when compared with the control (Table 2). These same treatments reduced $\mathrm{OL}_{\mathrm{T}}$ by $8.3(45 \%)$ and $6.5 \mathrm{~mm}$ (35\%) when compared with the control (Fig. 1). Laccase applied at the same activity was effective in reducing OL and OM, whereas laccase application at 0.206 units $/ \mathrm{cm}^{2}$ was not different from the control (Table 2; Fig. 2).

Treatment with 2.06 units $/ \mathrm{cm}^{2}$ laccase with and without guaiacol reduced $\mathrm{OM}(0$ to $5.0 \mathrm{~cm}$ ) by 7.6 and $7.8 \mathrm{mg} \cdot \mathrm{g}^{-1}$ and $\mathrm{OM}(0$ to $2.5)$ by 25.9 and $30.3 \mathrm{mg} \cdot \mathrm{g}^{-1}$, respectively, as compared with the control (Table 2; Fig. 2). Similarly, treatment with 2.06 units $/ \mathrm{cm}^{2}$ laccase with and without guaiacol increased SHC by $21.6(322 \%)$ and $6.3 \mathrm{~cm} \cdot \mathrm{h}^{-1}$ (94\%), respectively, over the control (Fig. 3). When compared with control, treatment with 2.06 units $/ \mathrm{cm}^{2}$ laccase without guaiacol reduced $\mathrm{L}_{\mathrm{S}}$ by $5.1, \mathrm{~L}_{\mathrm{I}}$ by 14.0 , and $\mathrm{L}_{\mathrm{T}}$ by $19.0 \mathrm{mg} \cdot \mathrm{g}^{-1}$, respectively (Table 3 ).

Turf quality. No significant differences in visual quality ratings were observed among the treatments except for the data collected after 38 weeks when 2.06 units $/ \mathrm{cm}^{2}$ of laccase exhibited a slight but significant reduction in turf quality when compared with the control treatment (Table 4). No significant differences from the control were observed for any treatment when means of the visual ratings were compared for the early ( 2 to 12

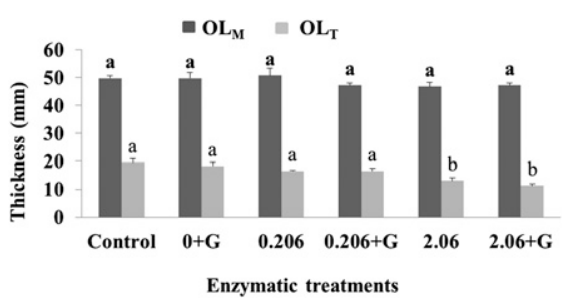

Fig. 1. Thatch $\left(\mathrm{OL}_{\mathrm{T}}\right)$ and mat layer thickness $\left(\mathrm{OL}_{\mathrm{M}}\right)$ after nine months of treatment on creeping bentgrass with three different levels of laccase [0 (control), 0.206 and 2.06 units/ $\left.\mathrm{cm}^{2}\right]$ with and without the mediator, guaiacol (G). Values are means of four replicates and error bars are standard errors. Bars with the same letter $\left(\mathrm{OL}_{\mathrm{M}}=\right.$ bolded and $\mathrm{OL}_{\mathrm{T}}=$ standard $)$ are not considered to be statistically different according to Fisher's protected least significant difference at $\alpha=0.05$.

weeks), late (32 to 38 weeks), and all periods (Table 4). When compared with the control, pots receiving 20.6 units $/ \mathrm{cm}^{2}$ laccase treatment had a small but significant decrease in grass index at 4 and 6 weeks after treatment initiation (Table 5). However, no significant differences in grass index values were observed after 6 weeks of treatment application. No visual differences among treatments for turf color or growth rate were observed over the duration of the experiment.

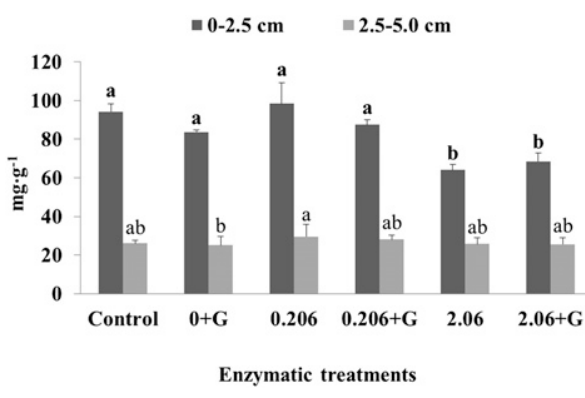

Fig. 2. Organic matter (OM) for 0 to $2.5 \mathrm{~cm}$ depth and 2.5 to $5.0 \mathrm{~cm}$ depth after nine months of treatment on creeping bentgrass with three different levels of laccase [0 (control), 0.206 and 2.06 units $\left./ \mathrm{cm}^{2}\right]$ with and without the mediator, guaiacol $(\mathrm{G})$. Values are means of four replicates and error bars are standard errors. Bars with the same letter [OM (0 to $2.5 \mathrm{~cm})=$ bolded and $\mathrm{OM}(2.5$ to $5.0 \mathrm{~cm})=$ standard] are not considered to be statistically different according to Fisher's protected least significant difference at $\alpha=0.05$.

\section{Discussion}

Laccase application. This is the first study to report the direct application of laccase enzyme to manage thatch-mat accumulation on creeping bentgrass. Application of laccase, especially at the 2.06 units $/ \mathrm{cm}^{2}$ activity level, proved to be effective in reducing thatch-mat depth, OM, and significantly 
increasing SHC. Carley et al. (2011) noted that $\mathrm{OM}$ accumulates rapidly near the soil surface by small annual accumulations that result in long-term effects. Our results indicate that application of $2.06 \mathrm{units} / \mathrm{cm}^{2}$ laccase alters $\mathrm{OM}$ dynamics in a positive manner by effectively reducing OM $(0$ to $2.5 \mathrm{~cm}$ ) and $\mathrm{OL}_{\mathrm{T}}$ in comparison with the control. However, an increase in $\mathrm{OM}$ (0 to 5.0

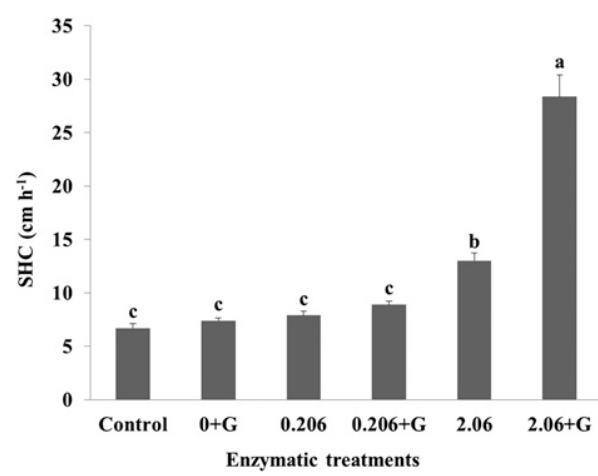

Fig. 3. Saturated hydraulic conductivity (SHC) after nine months of treatment on creeping bentgrass with three different levels of laccase [0 (control), 0.206 and 2.06 units $\left./ \mathrm{cm}^{2}\right]$ with and without the mediator, guaiacol $(\mathrm{G})$. Values are means of four replicates and error bars are SES. Bars with the same letter are not considered to be statistically different according to Fisher's protected least significant difference at $\alpha=$ 0.05 . $\mathrm{cm}$ ) and OL was observed for all the treatments over the experiment duration. Application of laccase enzyme was effective in reducing the rate of accumulation of thatch layer thickness and $\mathrm{OM}$.

The 2.06 units $/ \mathrm{cm}^{2}$ laccase treatment, after nine months of application, also resulted in increased SHC in which a three- and twofold increase in SHC was observed with applications of 2.06 units $/ \mathrm{cm}^{2}$ laccase with and without guaiacol, respectively. This increase can be explained on the basis of thatch layer thickness of the corresponding treatment. Thatch layer thickness more than $1.3 \mathrm{~cm}$ was reported to adversely affect water infiltration (McCarty et al., 2005) Thatch layer thickness for the treatment of 2.06 units $/ \mathrm{cm}^{2}$ with and without guaiacol after nine months of treatment was 11.2 and $13.0 \mathrm{~mm}$, respectively.

For both the two and nine months' sampling, no effect of guaiacol was observed and no interaction effect with laccase was observed except for SHC after nine months of application. The 2.06 units $/ \mathrm{cm}^{2}$ laccase treatment was ineffective when applied with guaiacol after two months of application except for a reduction in extractive-free $L_{S}$. The significant replication effect observed for $\mathrm{L}_{\mathrm{S}}$ and $\mathrm{L}_{\mathrm{I}}$ for two and nine months, respectively, may be associated with incomplete acid hydrolysis for some replications during autoclaving and unavailability of additional sample materials for reanalysis.
The lowest level of laccase application $\left(0.206\right.$ units $\left./ \mathrm{cm}^{2}\right)$ proved to be an ineffective treatment even after nine months of application for all the parameters measured. The 20.6 units $/ \mathrm{cm}^{2}$ treatment was applied for two months and resulted in no reduction of OM (0 to $5.0 \mathrm{~cm})$. However, this treatment did result in a significant reduction in OL and extractive-free lignin content $\left(\mathrm{L}_{\mathrm{S}}, \mathrm{L}_{\mathrm{I}}\right.$, and $\left.\mathrm{L}_{\mathrm{T}}\right)$ of the thatch layer.

Laccase application had only minor influences on turfgrass quality. A slight reduction in turf quality was indicated by lower grass index values during the first 4 to 6 weeks in response to the 20.6 units $/ \mathrm{cm}^{2}$ laccase treatment. However, visual quality ratings were not significantly different from controls except for one treatment combination at 38 weeks.

Treatment duration. If laccase was effective in enhancing OM degradation, it would seem reasonable to expect that effects would become more apparent over time. Samples were analyzed after two and nine months of treatment application. Laccase activity levels of 0.206 and 2.06 units $/ \mathrm{cm}^{2}$ area were continued for nine months. It was observed that treatment duration and the interaction of treatment duration with laccase treatments had a significant effect on $\mathrm{OM}(0$ to $5.0 \mathrm{~cm})$, $\mathrm{OL}$, and $\mathrm{L}_{\mathrm{S}}$ content.

Why laccase application? Studies in the past using various cultural management practices with different cultivation frequencies

Table 4. Mean visual turf quality ratings of creeping bentgrass made over time following continued treatment with different laccase and guaiacol solutions to greenhouse-grown plants.

\begin{tabular}{|c|c|c|c|c|c|c|c|c|c|c|c|c|c|}
\hline \multirow[b]{4}{*}{ Treatments ${ }^{\mathrm{z}}$} & \multicolumn{13}{|c|}{ Weeks } \\
\hline & \multicolumn{6}{|c|}{ Early } & \multicolumn{4}{|c|}{ Late } & \multirow[b]{2}{*}{ Early } & \multirow[b]{2}{*}{ Late } & \multirow[b]{2}{*}{ All } \\
\hline & 2 & 4 & 6 & 8 & 10 & 12 & 32 & 34 & 36 & 38 & & & \\
\hline & --------- & - & 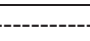 & 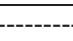 & - & --Visua & fgrass & ty $^{y}--$ & --- & -- & --o- & ----- & ------ \\
\hline 0L (control) & $7.1 \mathrm{ab}^{\mathrm{x}}$ & $6.7 \mathrm{a}$ & $8.3 \mathrm{ab}$ & $7.8 \mathrm{a}$ & $7.2 \mathrm{a}$ & $8.0 \mathrm{ab}$ & $7.9 \mathrm{a}$ & $7.9 \mathrm{a}$ & $8.3 \mathrm{a}$ & $8.5 \mathrm{a}$ & $7.5 \mathrm{a}$ & $8.0 \mathrm{a}$ & $\overline{7.8 \mathrm{a}}$ \\
\hline $0 \mathrm{~L}+\mathrm{G}$ & $7.0 \mathrm{ab}$ & $6.9 \mathrm{a}$ & $8.1 \mathrm{ab}$ & $7.7 \mathrm{a}$ & $7.1 \mathrm{a}$ & $8.1 \mathrm{a}$ & $7.8 \mathrm{a}$ & $7.7 \mathrm{a}$ & $8.1 \mathrm{a}$ & $8.4 \mathrm{a}$ & $7.4 \mathrm{a}$ & $7.9 \mathrm{a}$ & $7.8 \mathrm{a}$ \\
\hline $0.206 \mathrm{~L}$ & $7.2 \mathrm{a}$ & $6.8 \mathrm{a}$ & $8.2 \mathrm{ab}$ & $7.6 \mathrm{a}$ & $7.1 \mathrm{a}$ & $7.9 \mathrm{ab}$ & $8.0 \mathrm{a}$ & $8.0 \mathrm{a}$ & $8.1 \mathrm{a}$ & $8.4 \mathrm{a}$ & $7.4 \mathrm{a}$ & $7.8 \mathrm{a}$ & $7.8 \mathrm{a}$ \\
\hline $0.206 \mathrm{~L}+\mathrm{G}$ & $7.0 \mathrm{a}$ & $6.7 \mathrm{a}$ & $8.0 \mathrm{~b}$ & $7.8 \mathrm{a}$ & $7.3 \mathrm{a}$ & $7.8 \mathrm{~b}$ & $7.7 \mathrm{a}$ & $7.6 \mathrm{a}$ & $8.3 \mathrm{a}$ & $8.3 \mathrm{ab}$ & $7.4 \mathrm{a}$ & $7.8 \mathrm{a}$ & $7.5 \mathrm{a}$ \\
\hline $2.06 \mathrm{~L}$ & $7.2 \mathrm{a}$ & $7.0 \mathrm{a}$ & $8.3 \mathrm{ab}$ & $7.8 \mathrm{a}$ & $7.4 \mathrm{a}$ & $7.9 \mathrm{ab}$ & $7.9 \mathrm{a}$ & $7.9 \mathrm{a}$ & $8.1 \mathrm{a}$ & $8.1 \mathrm{~b}$ & $7.5 \mathrm{a}$ & $7.9 \mathrm{a}$ & $7.6 \mathrm{a}$ \\
\hline $2.06 \mathrm{~L}+\mathrm{G}$ & $6.9 \mathrm{ab}$ & $6.7 \mathrm{a}$ & $8.4 \mathrm{ab}$ & $7.8 \mathrm{a}$ & $7.3 \mathrm{a}$ & $7.7 \mathrm{~b}$ & $7.9 \mathrm{a}$ & $8.0 \mathrm{a}$ & $8.2 \mathrm{a}$ & $8.4 \mathrm{a}$ & $7.4 \mathrm{a}$ & $7.9 \mathrm{a}$ & $7.6 \mathrm{a}$ \\
\hline $20.6 \mathrm{~L}$ & $6.7 \mathrm{~b}$ & $6.9 \mathrm{a}$ & $8.4 \mathrm{a}$ & $7.8 \mathrm{a}$ & - & - & - & - & - & - & $7.5 \mathrm{a}$ & - & - \\
\hline $20.6 \mathrm{~L}+\mathrm{G}$ & $6.9 \mathrm{ab}$ & $6.7 \mathrm{a}$ & $8.2 \mathrm{ab}$ & $7.9 \mathrm{a}$ & - & - & - & - & - & - & $7.5 \mathrm{a}$ & - & - \\
\hline
\end{tabular}

${ }^{\mathrm{z}} \mathrm{L}$ denotes laccase level and $\mathrm{G}$ the addition of guaiacol, a mediator.

${ }^{\text {y } T u r f ~ q u a l i t y ~ w a s ~ v i s u a l l y ~ r a t e d ~ o n ~ a ~} 1$ to 9 scale with $9=$ outstanding, $6=$ acceptable, and $1=$ dead.

${ }^{\mathrm{x}}$ Means within a column followed by the same letter are not significantly different according to Fisher's protected least significant difference at $\alpha=0.05$.

Table 5. Mean grass index values of creeping bentgrass made over time following continued treatment with different laccase and guaiacol solutions to greenhousegrown plants.

\begin{tabular}{|c|c|c|c|c|c|c|c|c|c|c|c|c|c|}
\hline \multirow[b]{4}{*}{ Treatments $^{\mathrm{z}}$} & \multicolumn{13}{|c|}{ Weeks } \\
\hline & \multicolumn{6}{|c|}{ Early } & \multicolumn{4}{|c|}{ Late } & \multirow[b]{2}{*}{ Early } & \multirow[b]{2}{*}{ Late } & \multirow[b]{2}{*}{ All } \\
\hline & 2 & 4 & 6 & 8 & 10 & 12 & 32 & 34 & 36 & 38 & & & \\
\hline & & & & & & & index & & & & & & \\
\hline$\overline{\text { OL (control) }}$ & $7.03 \mathrm{ab}^{\mathrm{x}}$ & $6.47 \mathrm{a}$ & $7.47 \mathrm{a}$ & $6.71 \mathrm{a}$ & $7.70 \mathrm{a}$ & $8.17 \mathrm{ab}$ & $8.15 \mathrm{a}$ & $8.23 \mathrm{a}$ & $9.14 \mathrm{a}$ & $9.34 \mathrm{a}$ & $6.92 \mathrm{a}$ & $8.46 \mathrm{a}$ & $7.84 \mathrm{a}$ \\
\hline $0 \mathrm{~L}+\mathrm{G}$ & $7.11 \mathrm{ab}$ & $6.45 \mathrm{a}$ & $6.96 \mathrm{ab}$ & $6.53 \mathrm{a}$ & $7.94 \mathrm{a}$ & $8.31 \mathrm{a}$ & $8.20 \mathrm{a}$ & $8.47 \mathrm{a}$ & $9.04 \mathrm{a}$ & $9.06 \mathrm{a}$ & $6.76 \mathrm{a}$ & $8.50 \mathrm{a}$ & $7.81 \mathrm{a}$ \\
\hline $0.206 \mathrm{~L}$ & $7.21 \mathrm{a}$ & $6.40 \mathrm{ab}$ & $7.11 \mathrm{ab}$ & $6.55 \mathrm{a}$ & $7.70 \mathrm{a}$ & $7.96 \mathrm{ab}$ & $8.22 \mathrm{a}$ & $7.93 \mathrm{a}$ & $9.07 \mathrm{a}$ & $9.10 \mathrm{a}$ & $6.82 \mathrm{a}$ & $8.33 \mathrm{a}$ & $7.73 \mathrm{a}$ \\
\hline $0.206 \mathrm{~L}+\mathrm{G}$ & $7.15 \mathrm{ab}$ & $6.33 \mathrm{ab}$ & $6.90 \mathrm{ab}$ & $6.53 \mathrm{a}$ & $7.61 \mathrm{a}$ & $7.84 \mathrm{~b}$ & $8.36 \mathrm{a}$ & $8.10 \mathrm{a}$ & $9.06 \mathrm{a}$ & $9.34 \mathrm{a}$ & $6.73 \mathrm{a}$ & $8.39 \mathrm{a}$ & $7.72 \mathrm{a}$ \\
\hline $2.06 \mathrm{~L}$ & $7.10 \mathrm{ab}$ & $6.44 \mathrm{a}$ & $7.27 \mathrm{ab}$ & $6.53 \mathrm{a}$ & $7.66 \mathrm{a}$ & $8.14 \mathrm{ab}$ & $8.10 \mathrm{a}$ & $8.29 \mathrm{a}$ & $9.07 \mathrm{a}$ & $9.33 \mathrm{a}$ & $6.84 \mathrm{a}$ & $8.43 \mathrm{a}$ & $7.79 \mathrm{a}$ \\
\hline $2.06 \mathrm{~L}+\mathrm{G}$ & $6.94 \mathrm{ab}$ & $6.19 \mathrm{ab}$ & $7.50 \mathrm{a}$ & $6.49 \mathrm{a}$ & $7.84 \mathrm{a}$ & $8.20 \mathrm{ab}$ & $8.16 \mathrm{a}$ & $8.10 \mathrm{a}$ & $9.20 \mathrm{a}$ & $9.12 \mathrm{a}$ & $6.78 \mathrm{a}$ & $8.43 \mathrm{a}$ & $7.77 \mathrm{a}$ \\
\hline $20.6 \mathrm{~L}$ & $6.68 \mathrm{~b}$ & $6.02 \mathrm{~b}$ & $6.70 \mathrm{~b}$ & $6.72 \mathrm{a}$ & - & - & - & - & - & - & $6.53 \mathrm{~b}$ & - & - \\
\hline $20.6 \mathrm{~L}+\mathrm{G}$ & $6.92 \mathrm{ab}$ & $6.16 \mathrm{ab}$ & $6.96 \mathrm{ab}$ & $6.74 \mathrm{a}$ & - & - & - & - & - & - & $6.73 \mathrm{a}$ & - & - \\
\hline
\end{tabular}

${ }^{\mathrm{z}} \mathrm{L}$ denotes laccase level and $\mathrm{G}$ the addition of guaiacol, a mediator.

${ }^{\mathrm{y}}$ Grass index was recorded using TCM 500 based on the spectral reflectance with higher value representing higher quality.

${ }^{x}$ Means within a column followed by the same letter are not significantly different according to least significant difference at $\alpha=0.05$. 
have reported contrasting results for reduction in thatch-mat accumulation (Callahan et al., 1998; Carrow et al., 1987; Engel and Alderfer, 1967; McCarty et al., 2005; Rieke, 1994). Degradation of thatch-mat is reported either in terms of thatch-mat depth (Smiley et al., 1985; Soper et al., 1988) or in terms of thatch-mat depth and OM content by weight (Barton et al., 2009; McCarty et al., 2007). The OM content by weight in different studies is observed for different depths further making it difficult to compare the results (Barton et al., 2009; McCarty et al., 2005; Murray and Juska, 1977). In our study, however, we observed both OL thickness (thatch layer and mat layer) and OM content to provide a better comparison of the effectiveness of laccase on thatch-mat degradation.

Cultural practices like core aeration and vertical mowing are disruptive in nature and have shown to reduce the turf quality both aesthetically and physically, further reducing the playability of the turf (Barton et al., 2009; Landreth et al., 2008; McCarty et al., 2007). However, application of laccase is not disruptive and the effective treatment of 2.06 units $/ \mathrm{cm}^{2}$ laccase for nine months showed no overall reduction in turf quality of bentgrass.

Several non-destructive studies in the past using different treatments like sugars, mixtures of sugars and microbial inocula, and some enzymes like cellulase proved ineffective (Ledeboer and Skogley, 1967; Martin and Dale, 1980; McCarty et al., 2005; Murdoch and Barr, 1976). Most of these studies intended to increase microbial population to degrade OM. However, it is difficult to maintain higher microbial populations over sustained periods of time under field turfgrass management systems as a result of the inability to maintain proper microenvironment conditions required by particular microbial populations. Another reason that such studies were ineffective may be that they were focused on degradation of cellulose and hemicellulose by using cellulase enzyme and by increasing bacterial populations, whereas our hypothesis is that lignin degradation will open the cell wall structure of thatch biomass, hence making cellulose and hemicellulose more available for further microbial degradation. In our study, we used the end product from the white-rot fungi Trametes versicolor, the laccase enzyme, which is stable over a wide $\mathrm{pH}$ and temperature (Baldrian, 2006; Munoz et al., 1997; Stoilova et al., 2010; Thurston, 1994) to degrade lignin and to facilitate dethatching.

This greenhouse research demonstrated that biweekly application of laccase enzyme at 2.06 units $/ \mathrm{cm}^{2}$ can be effective in reducing the rate of accumulation of OM in highly maintained turf. However, low activity levels of laccase $\left(0.206\right.$ units $\left./ \mathrm{cm}^{2}\right)$ were ineffective in reducing the rate of thatch accumulation. Laccase application had little effect after two months but significantly reduced $\mathrm{OM}$ after nine months. Implications of these findings point to a novel approach to reduce OM in thatch or mat and its associated problems on golf greens. This approach can lead to the development of a new non-disruptive method for thatch management. Future research is needed to observe the effectiveness of laccase under field conditions as well as to optimize the activity level of laccase and the frequency of its application.

\section{Literature Cited}

Baldrian, P. 2006. Fungal laccases-Occurrence and properties. FEMS Microbiol. Rev. 30:215242.

Barton, L., G.G.Y. Wan, R.P. Buck, and T.D Colmer. 2009. Effectiveness of cultural thatchmat controls for young and mature kikuyu turfgrass. Agron. J. 101:67-74.

Beard, J.B. 1973. Turfgrass: Science and culture. Prentice Hall Inc., Englewood Cliffs, NJ.

Blanchette, R.A. 1984. Screening wood decayed by white rot fungi for preferential lignin degradation. Appl. Environ. Microbiol. 48:647-653.

Callahan, L.L., W.L. Sanders, J.M. Parham, C.A. Harper, L.D. Lester, and E.R. McDonald. 1998. Cultural and chemical controls of thatch and their influence on rootzone nutrients in bentgrass green. Crop Sci. 38:181-187.

Carley, D.S., D. Goodman, S. Sermons, W. Shi, D. Bowman, G. Miller, and T. Rufty. 2011. Soil organic matter accumulation in creeping bentgrass greens: A chronosequence with implications for management and carbon sequestration. Agron. J. 103:604-610.

Carrow, R.N. 2003. Surface organic matter in bentgrass greens. USGA Turfgrass Environ. Res. Online 2:1-10.

Carrow, R.N. 2004. Surface organic matter in bentgrass greens. Golf Course Mgt. 72:96-101.

Carrow, R.N., B.J. Johnson, and R.E. Burns. 1987. Thatch and quality of Tifway bermudagrass turf in relation to fertility and cultivation. Agron. J. 79:524-530.

Chen, Y.R. and S. Sarkanen. 2003. Macromolecular lignin replication: A mechanistic working hypothesis. PhytomTOMhemistry Rev. 2:235255.

Davin, L.B. and N.G. Lewis. 2003. A historical perspective on lignin biosynthesis: Monolignol, allylphenol and hydroxycinnamic acid coupling and downstream metabolism. Phytochem. Rev. 2:257-288.

Dunn, J.H., K.M. Sheffer, and P.M. Halisky. 1981. Thatch and quality of Meyer zoysia in relation to management. Agron. J. 73:949-952.

Engel, R.E. 1954. Thatch on turf and its control. Golf Course Rpt. 22:12-14.

Engel, R.E. and R.B. Alderfer. 1967. The effect of cultivation, top-dressing, lime, $\mathrm{N}$, and wetting agent on thatch development on 1/4-inch bentgrass over a 10-year period. N.J. Agr. Exp. Stn. Bull. 818:32-45.

Engelke, M.C., V.G. Lehman, W.R. Kneebone, P.F. Colbaugh, J.A. Reinert, and W.E. Knoop. 1995. Registration of 'Crenshaw' creeping bentgrass. Crop Sci. 35:589.

Hartwiger, C. 2004. The importance of organic matter dynamics: How research uncovered the primary cause of secondary problems. USGA Green Section Record 42:9-11.

Johnson, B.J., R.N. Carrow, and R.E. Burns. 1987. Bermudagrass turf response to mowing practices and fertilizer. Agron. J. 79:677-680.

Kang, K.H., J. Dec, H. Park, and J.M. Bollag. 2002. Transformation of the fungicide cyprodinil by a laccase of Trametes villosa in presence of phenolic mediators and humic acid. Water Res. 36:4907-4915.
Kirk, T.K., W.J. Connors, R.D. Bleam, W.F. Hackett, and J.G. Jeikus. 1975. Preparation and microbial decomposition of synthetic $\left[{ }^{14} \mathrm{C}\right]$ lignins. Proc. Natl. Acad. Sci. USA 72:2515-2519.

Kirk, T.K., W.J. Connors, R.D. Bleam, and G. Jeikus. 1976. Requirements for a growth substrate during lignin decomposition by two woodrotting fungi. Appl. Environ. Microbiol. 32: 192-194.

Kirk, T.K. and R.L. Farrell. 1987. Enzymatic 'combustion': The microbial degradation of lignin. Annu. Rev. Microbiol. 41:465-501.

Landreth, J., D. Karcher, and M. Richardson. 2008. Cultivating to manage organic matter in sand based putting greens: University of Arkansas researchers provide important insight for managing organic buildup on putting greens. USGA Turfgrass Environ. Res. Online 46:16-19.

Ledeboer, F.B. and C.R. Skogley. 1967. Investigations into the nature of thatch and methods for its decomposition. Agron. J. 59:320-323.

Martin, S.B. and J.L. Dale. 1980. Biodegradation of turf thatch with wood-decay fungi. Phytopathology 70:297-301.

McCarty, L.B. 2005. Best golf course management practices. $2^{\text {nd }}$ Ed. Prentice Hall Inc., Upper Saddle River, NJ.

McCarty, L.B., M.F. Gregg, and J.E. Toler. 2007. Thatch and mat management in an established creeping bentgrass green. Agron. J. 99:15301537.

McCarty, L.B., M.F. Gregg, J.E. Toler, J.J. Camberato, and H.S. Hill. 2005. Minimizing thatch and mat development in a newly seeded creeping bentgrass golf green. Crop Sci. 45: 1529-1535.

McCoy, E.L. 1992. Quantitative physical assessment of organic materials used in sports turf rootzone mixes. Agron. J. 84:375-381.

McWhirter, E.L. and C.Y. Ward. 1976. Effect of vertical mowing and aerification on golf green quality. Mississippi Agr. For. Exp. Stn. Res. Rpt. 2:1-2.

Mester, T., E. Varela, and M. Tien. 2004. Wood degradation by brown-rot and white-rot fungi. The Mycota II: Genetics and biotechnology. $2^{\text {nd }}$ Ed. Springer-Verlag, Berlin, Heidelberg, Germany.

Munoz, C., F. Guillen, A.T. Martinez, and M.J. Martinez. 1997. Laccase isozymes of Pleurotus eryngii: Characterization, catalytic properties, and participation in activation of molecular oxygen and $\mathrm{Mn}^{2+}$ oxidation. Appl. Environ. Microbiol. 63:2166-2174.

Murdoch, C.L. and J.P. Barr. 1976. Ineffectiveness of commercial microorganism inoculums in breaking down thatch in common bermudagrass in Hawaii. HortScience 11:488-489.

Murray, J.J. and F.V. Juska. 1977. Effect of management practices on thatch accumulation, turf quality, and leaf spot damage in common kentucky bluegrass. Agron. J. 69:365-369.

National Renewable Energy Laboratory. 2008. Determination of structural carbohydrates and lignin in biomass. 9 Aug. 2012. <http://www.nrel. gov/biomass/pdfs/42618.pdf>. NREL, Golden, $\mathrm{CO}$.

O'Brien, P. and C. Hartwiger. 2003. Aeration and topdressing for the $21^{\text {st }}$ century: Two old concepts are linked together to offer up-to-date recommendations. USGA Green Section Record 41:1-7.

Otjen, L. and R. Blanchette. 1987. Assessment of 30 white rot basidiomycetes for selective lignin degradation. Holzforschung 41:343-349.

Park, J.W., J. Dec, J.E. Kim, and J.M. Bollag. 1999. Effect of humic constituents on the transformation of chlorinated phenols and anilines in the 
presence of oxidoreductive enzymes or birnessite. Environ. Sci. Technol. 33:2028-2034.

Rieke, P.E. 1994. Sand topdressing: Where are we going? Golf Course Mgt. 62:36-38.

Roberts, E.C. and E.J. Bredakis. 1960. What, why and how of turfgrass root development. Golf Course Rpt. 28:13-24.

Roper, J.C., J.M. Sarkar, J. Dec, and J.M. Bollag. 1995. Enhanced enzymatic removal of chlorophenols in the presence of co-substrates. Water Res. 29:2720-2724.

Sartain, J.B. and B.G. Volk. 1984. Influence of selected white-rot fungi and topdressings on the composition of thatch components of four turfgrasses. Agron. J. 76:359-362.
SAS Institute Inc. 1994. The SAS system for Windows. Release 9.2. SAS Inst., Cary, NC.

Smiley, R.W., M. Crawen Fowler, R.T. Kane, A.M. Petrovic, and R.A. White. 1985. Fungicide effects on thatch depth, thatch decomposition rate, and growth of kentucky bluegrass. Agron. J. 77:597-602.

Soper, D.Z., J.H. Dunn, D.D. Minner, and D.A Sleper. 1988. Effects of clipping disposal, nitrogen, and growth retardants on thatch and tiller density in zoysiagrass. Crop Sci. 28:325-328.

Stoilova, I., A. Krastanov, and V. Stanchev. 2010. Properties of crude laccase from Trametes versicolor produced by solid-substrate fermentation. Adv. Bioscience Biotech. 1:208-215.
Thurston, C.F. 1994. The structure and function of fungal laccases. Microbiol. 140:19-26.

Weston, J.B. and J.H. Dunn. 1985. Thatch and quality of Meyer zoysia in response to mechanical cultivation and nitrogen fertilization, $\mathrm{p}$. 449-458. In: Lemaire, F. (ed.). Proc. $5^{\text {th }}$ Int. Turfgrass Res. Conf., Avignon, France. 1-5 July 1985. Institut National de la Recherche Agronomique, Paris, France.

White, R.H. and R. Dickens. 1984. Thatch accumulation in bermudagrass as influenced by cultural practices. Agron. J. 76:19-22.

Wong, D.W.S. 2009. Structure and action mechanism of ligninolytic enzymes. Appl. Biochem. Biotechnol. 157:174-209. 